\title{
A comparative study of the antioxidant activity and phytochemical composition of leaves extract between three varieties of date palm tree
}

\author{
Laouini Salah Eddine $^{1,2, *}$, Segni Ladjel ${ }^{3}$, Ouahrani Mohamed Ridha ${ }^{3}$ \\ ${ }^{1}$ Department of Industrial Chemistry, Faculty of Science and Technology, \\ Mohammed Kheider University, Biskra, Algeria \\ ${ }^{2}$ Faculty of Science and Technology, University of El-Oued, El-Qued, Algeria \\ ${ }^{3}$ Process Engineering Laboratory, Faculty of Science and Technology and Material Sciences, \\ University Kasdi Merbah Ouargla, Ouargla, Algeria \\ *E-mail address: Salah_laouini@yahoo.fr
}

\begin{abstract}
The date palm (Phoenyx dactylifera) consisted, for the people of southern Algeria, as tree of providence. Dates and their extracts are also used for many centuries as a medicine against allergy, inflammation, constipation and gastro-protective; they also have a high antibacterial and antioxidant activity. However, no studies are conducted to evaluate the extract from the leaves of date palm (Phoenyx dactylifera) in point of view of phytochemical composition, antimicrobial and the antioxidant activity. In this study, we have determined the phenolic compounds, antioxidant and antimicrobial activity of methanolic extracts from three varieties of leaves tree. According to the results the leaves extracts have very important values for polyphenols (215.24 to $156.46 \mathrm{mg} \mathrm{GAE} / \mathrm{g}$ DW) and high antioxidant activity (324. 45 to $206.21 \mathrm{mg}$ GAE / g DW), Diphenyl-1 picrylhydrazyl radical-scavenging activity $\left(\mathrm{IC}_{50}=2.98\right.$ to $4.83 \mu \mathrm{g} / \mathrm{ml}$ ); also the three extracts reveal a considerable antimicrobial potency and antifungal considerable activity, the diameter of inhibition is 35.2 to 39.5 $\mathrm{mm}$ (concentration $50 \mathrm{mg} / \mathrm{ml}$ ) for Candida albicans ATCC 90026 .
\end{abstract}

Keywords: Phoenyx dactylifera; polyphenol; DPPH radical-scavenging activity; reducing power; antimicrobial; south Algeria

\section{INTRODUCTION}

Phoenyx dactylifera is a tree of the family Arecaceae (palms), subfamily Coryphoideae and order Arecales. It is widely found in Saharian oasis and considered as a dominant tree in this region. The fruit tree grows in its shade which provides us cover vegetables and foods. This tree has been known since antiquity; its origin is located in North Africa, the Sahara, west of India and the Persian Gulf region. Also it is widespread in all the hot spots from the Atlantic to the Red Sea. If we adapt the estimates based on the shape and organoleptic properties of fruits, there are more than 600 varieties of these fruit trees. For Muslims, all over the world, dates are of religious importance and are mentioned several times in the Quran. In Algeria the Phoenyx dactylifera is an important tree [1], for people and plays principal roles in social, environmental and economic sectors [2]. As production, Algeria is one of the first 
producers of fruits of the date in the world; 500,000 t per year [3]. In Africa, medicinal plants are tradionally used; it was estimated over $80 \%$ of the population that they produce wide array of phytochemical; most of which are used, from the plant, as drugs source [4] in order to avoid the secondary effects undesirable (unwanted side-effects) of some synthetic chemical drugs. Recent reports indicate that there is an inverse relationship between the dietary intake of antioxidant-rich foods and the incidence of human disease. Two synthetic antioxidants, BHT and BHA which are used in the food industry, may be responsible for liver damage and carcinogenesis or toxic [5].

For these reasons, it is necessary to focus on others natural antioxidants extract from plants. Several chemical compounds extracted from plant leaves, but the most important is the polyphenols, which are secondary metabolites ubiquitously distributed in all higher plants [6]. Many new studies confirmed the antimicrobial activity of polyphenols occurring in vegetable foods and medicinal plants and that they act as anti-allergic, antimicrobial, anti-inflammatory, vasoprotector and anti-tumour agents [7]. The date is rich with phytochimicals like phenolic acids, sterols, procyanidins, flavanoids, carotenoids and anthocyanidin [8]. The biological and pharmacological activities of date are very important; the dates have activities antimutagenix, antiviral, antifungal, antiherlipidemic and hepatoprotective $[9,10]$. In all the studies carried out on the dates, in our knowledge, there is no scientific study and information of phytochemical, antioxidant capacity and antimicrobial activity concerning leaves extract of Phoenyx dactylifera.

The present work is undertaken to estimate the chemical composition, antimicrobial and antioxidant effect of leaves extract of three varieties of Phoenyx dactylifera growing in southeast of Algeria, and to evaluate any relationship between composition phytochemical and previous activities. As a result, new sources of antioxidant and antimicrobial agents can be obtained from leaves extracts hoping that we open more research horizons.

\section{EXPERIMENTAL}

\section{1. Chemicals and reagents}

Methanol, ethanol absolute, chloroform $\left(\mathrm{CHCl}_{3}\right)$ and ultra pure water were purchased from Merk (France), folin-ciocalteu reagent, Diphenyl-1 picrylhydrazyl (DPPH), potassium ferricyanide $\left[\mathrm{K}_{3} \mathrm{Fe}(\mathrm{CN})_{6}\right]$, butylated hydroxyanisole (BHA), butylated hydroxytoluene (BHT), chlorogenic acid were procured from Sigma-Aldrich Inc (Paris, France). All other chemicals and reagents were analytical-reagent, sodium carbonate $\left(\mathrm{Na}_{2} \mathrm{CO}_{3}\right)$, gallic acid, sodium nitrate $\left(\mathrm{NaNO}_{2}\right)$, aluminium chloride $\left(\mathrm{AlCl}_{3}\right)$, sodium hydroxide $(\mathrm{NaOH})$, catechin, hydrochloric acid $(\mathrm{HCl})$, quercetin, linoleic acid, sodium phosphate, tricloroacetic acid $\left(\mathrm{CCl}_{3} \mathrm{COOH}\right)$, ferric chloride $\left(\mathrm{FeCl}_{3}\right)$, sulfuric acid $\left(\mathrm{H}_{2} \mathrm{SO}_{4}\right)$ and ammonium molybdate. The following reagents were used for the microbial activity: Nutrient agar.

\section{2.Plant material Preparation of extracts}

The aerial parts of Phoenyx dactylifera (leaves) of three trees were collected in March 2011 from Debila (Djedeida) located in Wilaya of El-Oued southeast Algeria (33 $07^{\circ} 00^{\prime \prime} \mathrm{N}$ $\left.7^{\circ} 11^{\prime} 00^{\prime \prime} \mathrm{E}\right)$ and were grown for six months before being used. This species was identified by Pr. Ouahrani M. Ridha Department of Chemistry, Kasdi Merbah University. The leaves were dried in well ventilated spaces at room temperature, powdered and sifted in a sieve $(0.750 \mu \mathrm{m})$ before use. 
The powder of each plant material (50 g) was extract three times with $500 \mathrm{~mL}$ of $80 \%$ v/v (MeOH: water) during $48 \mathrm{~h}$, stirred with condition $350 \mathrm{rpm}$ and $35^{\circ} \mathrm{C}$ using an orbital shaken. The extracts were filtered by Whatman $\mathrm{N}^{\circ} .1$. The filtrate was concentrated under reduced pressure at $40{ }^{\circ} \mathrm{C}$ by rotary evaporator (BUCHI R-210, Switzerland) to eliminate the methanol, and stored in $-4{ }^{\circ} \mathrm{C}$ to give a crude extract yielding $8.25 \mathrm{~g}$ for Ghars, $9.56 \mathrm{~g}$ for Deglat Nour and $7.82 \mathrm{~g}$ for Hamraya, diluted in methanol and distilled water for next concentrations needed in this work.

\section{3. Determination of total polyphenol content}

The concentration of total polyphenols compounds in the extracts was estimated by the folin-ciocalteu method with some modification [11]. Briefly, a dilute solution of each extract in $\mathrm{MeOH}(1 \mathrm{~mL})$ was mixed with $1 \mathrm{~mL}$ of folin-ciocalteu reagent, followed by $1 \mathrm{~mL}$ of a sodium carbonate $(10 \% \mathrm{w} / \mathrm{v})$ after $4 \mathrm{~min}$. The reaction mixture was incubated for $60 \mathrm{~min}$ at room temperature; the absorbance of reaction mixture at $700 \mathrm{~nm}$ was measured, the blank's prepared with the same procedure described above except that the samples solution was substituted by $1 \mathrm{~mL}$ of $80 \%$ methanol. The concentration of total polyphenols in the extracts was expressed as mg GAE per $\mathrm{g}$ of dry weight using UV-Visible (Shimadzu UV-1800, Japan) and the equation of calibration curve: $\mathrm{Y}=0.00778 \mathrm{x}+0.26193, \mathrm{R}^{2}=0.991, \mathrm{x}$ was the absorbance and $Y$ was the gallic acid equivalent. All results presented are means $( \pm \mathrm{SEM})$ and were analyzed in three replications.

\section{4. DPPH radical-scavenging activity}

A $1 \mathrm{~mL}$ aliquot of each extract was added to $0.5 \mathrm{~mL}$ of DPPH methanolic solution $(7.8$ mg DPPH in $100 \mathrm{~mL}$ methanol $100 \%$ ). The mixture was vigorously shaken and left to stand in the dark for $30 \mathrm{~min}$ at room temperature [12]. The antioxidant activity was then measured by the decrease in absorption at $517 \mathrm{~nm}$ using UV-Visible spectrophotometer (Shimadzu UV1800 , Japan) and corresponds to the extract ability to reduce the radical DPPH* to the yellowcolored DPPH. The antiradical activity was expressed as $\mathrm{IC}_{50}(\mu \mathrm{g} / \mathrm{mL})$, the antiradical dose required to cause $50 \%$, was obtained by interpolation from linear regression analysis and calculated by the following equation:

$$
\text { DPPH scavenging activity }(\%)=\left(\mathrm{A}_{0}-\mathrm{A}_{1}\right) / \mathrm{A}_{\mathrm{o}} \times 100
$$

where $A_{o}$ is the absorbance of control at $30 \mathrm{~min}, A_{1}$ is the absorbance of the sample extract at $30 \mathrm{~min}$. All results presented are means $( \pm \mathrm{SEM})$ and were analyzed in three replications.

\section{5. Reducing power assay}

$0.2 \mathrm{~mL}$ of sample extracts of different concentrations was added to $2.5 \mathrm{~mL}$ sodium phosphate buffer $(0.2 \mathrm{~mol} / \mathrm{L}$, pH 6.6$)$ and $2.5 \mathrm{~mL}$ of $\mathrm{K}_{3} \mathrm{Fe}(\mathrm{CN})_{6} 1 \%$, the mixture incubated at $50{ }^{\circ} \mathrm{C}$ for $20 \mathrm{~min}$. After this, $2.5 \mathrm{~mL}$ of tricloroacetic acid $10 \%$ were added $(10 \%$, w/v, in water) and centrifuged at $1000 \mathrm{rpm}$ for $10 \mathrm{~min}$ at room temperature, the upper layer of solution $5 \mathrm{~mL}$ was mixed with $5 \mathrm{ml}$ of distilled water and $1 \mathrm{~mL}$ ferric chloride $0.1 \%$ [13], the absorbance measured at $700 \mathrm{~nm}$ again the blank using UV-Visible spectrophotometer (Shimadzu UV-1800, Japan), the extract concentration providing $50 \%$ inhibition $\left(\mathrm{EC}_{50}\right)$ was calculated from the graph of measured absorbance. The values were expressed as mg per $1 \mathrm{~L}$ of leave extracts, all determinations were performed in triplicate. 


\section{6. Estimation of total antioxidant}

The total antioxidant capacity of the crude extract of leaves was evaluated by the method based on the reduction of Mo (VI) to Mo (V) by formation of the green phosphate/ $\mathrm{M}(\mathrm{V})$ [14]. In the appendorf tube, $0.3 \mathrm{~mL}$ of methanols extract $80 \%$ known concentration was added to $2.7 \mathrm{~mL}$ mol of the reagent solution $(0.6 \mathrm{M}$ sulfuric acid, $28 \mathrm{mM}$ sodium phosphate and $4 \mathrm{mM}$ ammonium molybdate). The tubes were capped and incubated in a boiling water bath (Mammert D-91126 Schwabach FRG, Germany) at $95{ }^{\circ} \mathrm{C}$ for 90 min, the blank is prepared with the same procedure described above but we replace the volume of simple extract by $0.3 \mathrm{~mL}$ methanol, the absorbance was calculated at $695 \mathrm{~nm}$. The antioxidant capacity was expressed as mg GAE per gram of dry plant powder (me GAE/g DW) and expressed as $\mathrm{IC}_{50}(\mu \mathrm{g} / \mathrm{mL})$, the dose required to cause $50 \%$ of inhibitiob, was obtained by interpolation from linear regression analysis and calculated by the following equation: All determinations were performed in triplicate.

\section{7. Antimicrobial activity assays}

\section{7. 1. Microorganisms}

Eleven bacteria strains were used in this study; the bacterial cells assayed included two gram-positive, Staphylococcus aureus ATCC [15] and Bacillus cereus ATCC 14579. For the gram-negative, nine bacterial strains were used, Escherchia coli ATCC 35218, Salmonella arizona DM 35605, Pseudomonas aerigunosa ATCC 27853, Pseudomonas aerigunosa HM 627626, Pseudomonas aerigunosa HM 627575, Pseudomonas aerigunosa ATCC 15442, Pseudomonas aerigunosa HM 627579, Pseudomonas putida HM 6227611 [16], and Agrobacterium tumefaciens B6 C58 [17]. All strains were obtained from the Laboratory of Waste Water Treatment, Centre of Research and Technologies of Water (Tunisia).

\section{7. 2. Incubation conditions}

NA was used culture medium for bacteria, incubated for $24 \mathrm{~h}$ at $37{ }^{\circ} \mathrm{C}$ and yeasts were cultured in SDA (4\% dextrose, $2 \%$ neopeptone and $1.7 \%$ agar) for $24-48 \mathrm{~h}$ at $30^{\circ} \mathrm{C}$ [18].

\section{7. 3. Disc diffusion assay}

Methanol extracts of Phoenyx dactylifera L were dissolved in methanol-water $80 \%$ for a final concentration $50 \mathrm{mg} / \mathrm{mL}$ and filter-sterilized through a 0.45 membrane filter. The antimicrobial activity was estimated by method of disc diffusion, $100 \mu \mathrm{L}$ of suspension for each microorganism $10^{8}$ colony-forming units $(\mathrm{CFU}) / \mathrm{mL}$ of bacteria were put in the plastic petri plates containing $20 \mathrm{~mL}$ of nutrient agar, after they were placed in the petri sterilized filter paper disc (6mm in diameter) and were soaked with $15 \mu \mathrm{L}$ of the $50 \mathrm{mg} / \mathrm{mL}$ of each methanolic extracts $(150 \mu \mathrm{g} /$ disc $)$.

The $\mathrm{MeOH} 80 \%$ was used as a negative control and polymyxine $\mathrm{B}$ it was the positive control, prepared with the same procedure described above except that the methanol extract was substituted by $15 \mu \mathrm{L}$ of positive control at $50 \mathrm{mg} / \mathrm{mL}$, the diameter of the inhibition zone around each disc was measured for three replicates [18].

\section{8. Statistical analysis}

Data were expressed and were presented as mean values \pm SD (standard deviations). All measurements were carried out in three experiments (all the analyses in the present study 
work which was done in duplicate determinations). Statistical calculations were carried out by OriginPro version 8 software (Prolab), Correlations were obtained by Pearson correlation coefficient in bivariate correlations. $\mathrm{P}$ values $<0.05$ were regarded significant and $\mathrm{P}$ values $<$ 0.01 were regarded very significant.

\section{RESULTS AND DISCUSSION}

\section{1. Extract yield}

The methanol is a solvent extract which have significant amounts of polyphenols compounds and used in several recent studies, it is the best solvent of antimicrobial substances compared with the other solvents and given an elevated antioxidant activity $[16,17,19]$. The results of extract yield for each variety of Phoenyx dactylifera Lare mentioned in table 1, which shows the extraction yield (g/100 g dry weight), the Deglet Nour variety gives the highest yield $(19.12 \pm 0,108 \% \mathrm{w} /$ while the intermediate value $(16.50 \pm 0.140 \%)$ was obtained from the Ghars extract. the lowest value was found for Hamraya. The mass yield obtained for methanolic extract of leaves A. roseum var. odoratissimum about $6.3 \%$ [19] and $16.1 \%$ for methanolic extract of Rhizoma Smilacis Chinae [20].

\section{2.Total polyphenol}

The total polyphenol content of methanol extract of three varieties of Phoenyx dactylifera is shown in Table 1, the range was from $215.24 \pm 9.25$ to $156.46 \pm 4.21 \mathrm{mg} \mathrm{GAE} / \mathrm{g}$ DW. The higher amount of these compounds found in Ghars variety $215.24 \pm 6.25 \mathrm{mg}$ GAE $/ \mathrm{g}$ DW, $179.30 \pm 5.43 \mathrm{mg}$ GAE/g DW in Deglet Nour and the lowest concentration obtained from Hamraya variety $156.46 \pm 4.21 \mathrm{mg}$ GAE$/ \mathrm{g}$ DW, these concentrations significantly higher if are compared to other medicinal plants like G. multifolial $12.36 \mathrm{mg}$ GAE/g DW and G. villosa $20.81 \mathrm{mg} \mathrm{GAE} / \mathrm{g}$ DW [21], and $70.07 \mathrm{mg} \mathrm{GAE} / \mathrm{g}$ DW for M. edule [22]. The quantity of phenolic compounds in leaves samples is greatly influenced by soil, water irrigation, environmental condition, genotype (cultivate/variety) agronomic practices (fertilization and pest management). The extracts of these trees showed high concentration of polyphenol, flavanoid and flavonol content, for these raisons antioxidant and antimicrobial activity were determined.

Table 1. Mass yield of leaves obtained by methanol $80 \%$ of three varieties of Phoenyx dactylifera L.

\begin{tabular}{|c|c|c|c|}
\hline Plant species & $\begin{array}{c}\text { dry weight } \\
\text { extract } \\
\text { g/50 g }\end{array}$ & Yield (\%) w/w & $\begin{array}{c}\text { Polyphenols } \\
\text { (mg GAE/G DW) }\end{array}$ \\
\hline Gars & $8.25 \pm 0.07$ & $16.50 \pm 1.15$ & $215.24 \pm 9.25$ \\
Deglet Nour & $9.56 \pm 0.08$ & $19.12 \pm 0.10$ & $179.30 \pm 4.21$ \\
Hamraya & $7.82 \pm 0.04$ & $15.64 \pm 0.08$ & $156.64 \pm 5.43$ \\
\hline
\end{tabular}

Results are expressed as the mean \pm standard deviation of three independent experiments. Values with different row are significantly $(\mathrm{P}<0.05)$. 


\section{DPPH assay}

The DPPH radical scavenging assay is an easy rapid and sensitive method for the antioxidant Screening of plant extracts [23].

The DPPH radical scavenging activity of methanolic extract leaves of the three varieties of Phoenyx dactylifera is presented in Table 2.

For crude extract of Ghars variety obtained the higher value (IC50 $=2.98 \pm 0.08$ $\mu \mathrm{g} / \mathrm{mL}$ ), the intermediate value found in Deglet Nour (IC50 $=3.74 \pm 0.07 \mu \mathrm{g} / \mathrm{mL}$ ) and the lowest amount obtained in Hamraya variety (IC50 $=4.83 \pm 0.10 \mu \mathrm{g} / \mathrm{mL}$ ).

If we compare these values with other methanolic extracts of leaves, the IC50 $=230.5$ $\pm 0.3 \mu \mathrm{g} / \mathrm{mL}$ for Petroselinum sativum and IC50 $=600.1 \pm 0.1 \mu \mathrm{g} / \mathrm{mL}$ for Beta vulgaris var cicla [17].

The antioxidant capacity of different varieties of Phoenyx dactylifera is higher than the positive control BHT (IC50 = $11.7 \pm 0.3 \mu \mathrm{g} / \mathrm{mL}$ ), this antioxidant capacity free radical scavenger DPPH related with the quantity of total polyphenol composition [24,25].

Moreover, the antimicrobial activity of these compounds according in plants has been extensively investigated against a wide range of microorganisms [26].

\section{3. Reducing power}

$\mathrm{Fe}^{3+}$ reductions are often used as an indicator of electron-donating activity, which is an important mechanism of phenolic antioxidant action, and can be strongly correlated with other antioxidant properties [27].

The reducing power is confirmed by the change of yellow colour of the test solution to various shades of green and blue depending on the concentration of the plant extract, the high reducing power was obtained in methanolic extract of Ghars $\left(\mathrm{IC}_{50}=13.28 \pm 0.05 \mu \mathrm{g} / \mathrm{mL}\right)$, the intermediate value obtained from Deglet Nour extract $\left(\mathrm{IC}_{50}=32.73 \pm 1.35 \mu \mathrm{g} / \mathrm{mL}\right)$ and the lowest value founded in Hamraya extract $\left(\mathrm{IC}_{50}=42.26 \pm 2.04 \mu \mathrm{g} / \mathrm{mL}\right)$.

The reducing power of all extracts were significantly higher than those of standard antioxidant $\left(\mathrm{BHA}, \mathrm{IC}_{50}=62.43 \pm 2.55 \mu \mathrm{g} / \mathrm{mL}\right)$ and chlorogenic acid $\left(\mathrm{IC}_{50}=49.41 \pm 2.37\right.$ $\mu \mathrm{g} / \mathrm{mL})$, the results are shown in Table 2 .

\section{4. Total antioxidant activity}

The total antioxidant activity of methanolic extracts of leaves range from $324.45 \pm 11.43$ to $206.21 \pm 9.14 \mathrm{mg} \mathrm{GAE} / \mathrm{g} \mathrm{DW}$, the high values are $324.45 \pm 11.43 \mathrm{mg}$ GAE/g DW for Ghars leaves extract, then $218.15 \pm 7.55$ for Deglet Nour leaves extract and finally $206.21 \pm 9.14 \mathrm{mg}$ GAE/g DW for Hamraya leaves extract.

These results exhibit strong values and confirmed the high antioxidant activity of leaves extract of Phoenyx dactylifera founded in DPPH, $\beta$-Carotene and reducing power, the results are presented in Table 2. 
Table 2. DPPH radical-scavenging activity, reducing power of extracts and standards expressed as $\left(\mathrm{IC}_{50}\right.$ in $\left.\mu \mathrm{g} / \mathrm{ml}\right)$. Total antioxidant activity (mg GAE/g DW).

\begin{tabular}{|c|c|c|c|}
\hline $\begin{array}{c}\text { Plant species and } \\
\text { standards }\end{array}$ & DPPH test & Reducing power & $\begin{array}{c}\text { Total antioxidant } \\
\text { activity }\end{array}$ \\
\hline Ghars & $2.98 \pm 0.08$ & $13.28 \pm 0.05$ & $206.21 \pm 09.14$ \\
\hline Deglet Nour & $3.74 \pm 0.07$ & $32.73 \pm 1.35$ & $218.15 \pm 07.55$ \\
\hline Hamraya & $4.83 \pm 0.10$ & $42.26 \pm 2.04$ & $324.45 \pm 11.43$ \\
\hline BHT & $11.7 \pm 0.30$ & - & - \\
\hline BHA & - & $62.43 \pm 2.55$ & - \\
\hline chlorogenic acid & - & $49.41 \pm 2.37$ & - \\
\hline
\end{tabular}

Data are expressed as means \pm standard deviation of triplicate samples. Values with different row are significantly $(\mathrm{P}<0.05)$.

\section{5. Antimicrobial activity}

The results of the antibacterial activity of methanol extracts of studies tree againt a set of Gram-positive (Staphylococcus aureus ATCC and Bacillus cereus ATCC 14579), and Gram-negative (Escherchia coli ATCC 35218, Salmonella arizona DM 35605, Pseudomonas aerigunosa ATCC 27853, Pseudomonas aerigunosa HM 627626, Pseudomonas aerigunosa HM 627575, Pseudomonas aerigunosa ATCC 15442, Pseudomonas aerigunosa HM 627579 and Pseudomonas putida HM 6227611) are sumarised in Table 3. All methanolic extracts of leaves were active on all bacterias tested except one (Agrobacterium tumefaciens B6 C58), the Gram-positive bacterias appeared more sensitive than the bacteria of gram-negative.

The zone diameter of inhibition ranged from $19.8 \pm 0.8 \mathrm{~mm}$ at $17.4 \pm 0.8 \mathrm{~mm}$, the higher antibacterial activity founded in Staphylococcus aureus ATCC (19.8 $\pm 0.5 \mathrm{~mm})$ from leaves extract of Ghars and the lowest sensitivity obtained from Pseudomonas aerigunosa ATCC $27853(10.5 \pm 0.3)$ from leaves extract of Hamraya.

This antibacterial activity is higher than the postivie contrôle polymyxine $\mathrm{B}$, the zone diameter of inhibition ranged from $12.5 \pm 0.5 \mathrm{~mm}$ at $8.5 \pm 0.3 \mathrm{~mm}$. Polyphenol possess antibacterial activities [27]. For antifungal activity, the methanolic extracts give the activity power, the zone diameter of inhibition ranged from $11.5 \pm 1 \mathrm{~mm}$ at $20.2 \pm 0.8 \mathrm{~mm}$.

The methanolic extracts from leaves of Ghars variety exhibited the higher antifungal activity, enregistred zone diameter of inhibition $15.4 \pm 1 \mathrm{~mm}$ for Candida albicans ATCC $9002617.4 \pm 1.3 \mathrm{~mm}$ for Pyrenophora teres Fand and $20.2 \pm 0,8 \mathrm{~mm}$ for Ptytophtora nicotina, methanolic extract of Hamraya exhibited the low power antifungal.

The results are shown in table 3. Several authors supported these results, the date extract may have multiple effects on Candida and with further studies may be of therapeutic uses and inhibits the infectivity of Pseudomonas ATCC 14209-B1 [28,29]. 
Table 3. Antibactrial and antifungal activity of methanolic extracts leaves of different varieties of Phoenyx dactylifera $L$.

\begin{tabular}{|c|c|c|c|c|}
\hline \multirow{2}{*}{$\begin{array}{c}\text { Microorganisms } \\
\text { Bacteria }\end{array}$} & \multicolumn{4}{|c|}{ Diameter of zone inhibition } \\
\hline & Ghars extract & $\begin{array}{l}\text { Deglet Nour } \\
\text { extract }\end{array}$ & Hamraya extract & $\begin{array}{c}\text { polymyxine } \\
\text { B }\end{array}$ \\
\hline \multicolumn{5}{|l|}{ Bacteria } \\
\hline $\begin{array}{c}\text { Staphylococcus aureus } \\
\text { ATCC }\end{array}$ & $19.8 \pm 0.5$ & $17.4 \pm 0.8$ & $14.4 \pm 0.6$ & $12.5 \pm 0.5$ \\
\hline $\begin{array}{c}\text { Bacillus cereus } \\
\text { ATCC } 14579\end{array}$ & $19.3 \pm 0.6$ & $16.5 \pm 0.5$ & $14.5 \pm 0.5$ & $11.0 \pm 0.4$ \\
\hline $\begin{array}{c}\text { Escherchia coli } \\
\text { ATCC } 35218\end{array}$ & $14.7 \pm 0.5$ & $12,8 \pm 0.6$ & $11.5 \pm 0.6$ & $08.5 \pm 0.0$ \\
\hline $\begin{array}{l}\text { Agrobacterium tumefaciens } \\
\text { B6 C58 }\end{array}$ & na & na & na & $08.5 \pm 0.3$ \\
\hline $\begin{array}{c}\text { Pseudomonas aerigunosa } \\
\text { ATCC } 27853\end{array}$ & $16.7 \pm 0.6$ & $15.6 \pm 0.4$ & $15.2 \pm 0.6$ & $11.5 \pm 0.0$ \\
\hline $\begin{array}{c}\text { Pseudomonas aerigunosa } \\
\text { HM } 627626\end{array}$ & $14.6 \pm 0.5$ & $13.2 \pm 0.5$ & $13.5 \pm 0.4$ & $10.4 \pm 0.5$ \\
\hline $\begin{array}{c}\text { Pseudomonas aerigunosa } \\
\text { HM } 627575\end{array}$ & $14.2 \pm 0.5$ & $13.5 \pm 0.6$ & $13.1 \pm 0.4$ & $11.5 \pm 0.5$ \\
\hline $\begin{array}{c}\text { Pseudomonas aerigunosa } \\
\text { ATCC } 15442\end{array}$ & $16.8 \pm 0.3$ & $15.6 \pm 0.6$ & $13.5 \pm 0.0$ & $12.0 \pm 0.4$ \\
\hline $\begin{array}{c}\text { Pseudomonas aerigunosa } \\
\text { HM } 627579\end{array}$ & $15.5 \pm 0.2$ & $15.5 \pm 0.4$ & $14.2 \pm 0.0$ & $12.5 \pm 0.3$ \\
\hline $\begin{array}{c}\text { Pseudomonas putida } \\
\text { HM 6227611 }\end{array}$ & $15.7 \pm 0.5$ & $14.2 \pm 0.5$ & $13.5 \pm 0.5$ & $11.8 \pm 0.5$ \\
\hline \multicolumn{5}{|c|}{ Fungi } \\
\hline $\begin{array}{l}\text { Candida albicans } \\
\text { ATCC } 90026\end{array}$ & $15.4 \pm 1.0$ & $14.5 \pm 0.5$ & $12.0 \pm 1.0$ & na \\
\hline Pyrenophora teres F & $17.4 \pm 1.3$ & $15.5 \pm 0.5$ & $12.4 \pm 0.5$ & $11.5 \pm 1.0$ \\
\hline Ptytophtora nicotina & $20.5 \pm 0.8$ & $17.0 \pm 1.0$ & $15.5 \pm 1.2$ & $12.5 \pm 0.5$ \\
\hline
\end{tabular}

na: not active. Data are expressed as means \pm standard deviation of triplicate samples.

\section{CONCLUSION}

We think that the present study is the first to investigate the phytochemical composition, antioxidant and antimicrobial activity of methanolic extracts of three varieties of Phoenyx dactylifera grown in Southeast Algeria. This study shows that considerable variety exists between the three methanolic extracts of leaves of Ghars, Deglet Nour and Hamraya. We 
found high amount of total polyphenol content, the Ghars variety exhibits the high amount of these compounds. On the other hand, the results of antioxidant activity tests present the strong capacity of three methanolic extracts, higher than the standard antioxidants (BHA, BHT and chlorogenic acid). Finally, all extracts show the high antimicrobial activity for the microorganisms tests (bacteria and fungi) exceeded most of the time the positive control. The good correlation found between activity and phytochemical contents indicates that effects observed could be attributed to phenolic compounds. This data suggest the strong potential of these extracts as a natural source of phenolic compounds, antioxidant and antimicrobial and may be considered in future to replace synthetic preservatives and drugs in pharmaceutical and food industry.

\section{ACKNOWLEDGEMENTS}

The authors wish to thank gratefully Prof. Touhami Lanez Director of Valorisation and Technology of Resource Saharian Laboratory (University of El-Oued, Algeria) for his continuous support during the work and the use of all laboratory materials, reagents and products. Thanks are also to Dr. Mokni Sonia researcher in Wastewater Treatment Laboratory, Water Researches and Technologies Center, Technopark of Borj Cedria, Tunisia and Prof. Chedly Abdelly Director of Biotechnogy Center, Ecopark of Borj Cedria, Tunisia for their help during the experimental procedures and for the explanation of all techniques used in this study.

\section{References}

[1] Al Farsi M., Alasalvar C., Morris A., Baron M., Shahidi F. J., Agric. Food Chemistry 53 (2005) 7592-7599.

[2] EL Amer A., Guido F., Behiji S. E., Manel I., Nesrine Z., Ali F., et al, Food Chemistry 127 (2011) 1744-1754.

[3] Abida B. D., Salem B., Nabil S., Abdelhakim M., Powder Technology 208 (2011) 725-730.

[4] Oyedemi S. O. A., Afolayan J, Asian Pac J. Trop Med 4 (2011) 952-958.

[5] Moure A., Cruz G. M., Franco D., Dominguez J. M., Sineiro J. H., et al, Food Chemistry $72(2011) 145-171$.

[6] Maria Daglia, Curr Opin. Biotech 23 (2011) 174-181.

[7] Jayaprakasha G. K, Jena B. S., Negi P. S., Sakariah K. K, Food Chemistry 73 (2001) 285-290.

[8] Muanda F. N., Solimani R., Diop B., Dikco A., Food Sci. Technol 44 (2011) 1865-1872.

[9] Vayalil P. K., Agric. Food Chem 50 (2002) 610-617.

[10] Jassim S. A. A., Naji M. A., Evid-based compl. Alt 15 (2008) 1-6.

[11] Moreira L., Dias L. G., Pereira J. A., Estevinho L., Food. Chem Toxicol 46 (2008) 3482-3485.

[12] Hatano T., Kagaw H., Yasuhara T., Okuda T., Chem. Pharm Bull 36 (1989) 2090-2097. 
[13] Gulcin I., Oktay M., Kirecci E., Kufrevioglu O. I., Food Chemistry 83 (2003) 371-382.

[14] Prieto P., Pineda M., Aguilar M., Anal Biochem 269 (1999) 337-341.

[15] Kilani-Jaziri S., Bhouri W., Skandrani I., Limem I., Chekir-Ghedira L., Ghedira K., S. Afr. J. Bot. 77 (2011) 767-776.

[16] Penna C., Marino S., Vivot E., Cruañes M. C., Munoz J. D., Cruañes J., et al, J. Ethnopharmacol. 77 (2011) 37-40.

[17] Edziri H., Ammar S., Souad L., Mahjoub M. A., Mastouri M., Aouni M., et al, S. Afr. J. Bot. 78 (2011) 252-256.

[18] Castilho P. C., Savluchinske-Feio S.,Weinhold T., Gouveia S. G., Food Control 23 (2012) 552- 558.

[19] Selma D., Imed H., Saloua F., Yassine M., Herve'C., Belgacem H., et al, J. Fonct Foods 4 (2010) 423-432.

[20] Qing-Feng Z., Yu-Xian G., Xinchen B. S., Guodong Z., Wen-Jun W., Food Chemistry 133 (2012) 140-145.

[21] Daniels C. W., Rautenbach F., Mabusela W. T., Valentine A. J., Marnewick J. L., S. Afr. J. Bot. 77 (2011) 711-717.

[22] Falleh H., Ksouri R., Oueslati S., Guyot S., Magné C., Abdelly C., Food. Chem. Toxicol. 47 (2009) 2308-2313.

[23] Hemalatha S., Lalitha P., Arulpriya P., Der Pharma Chemica 2 (2010) 84-89.

[24] Julia V., Mario R., Maria C. L, LWT - Food Sci. Technol 45 (2012) 28-35

[25] Neha B., Harinder S. O., Dewinder S. U., Ramabhau P. T., Food Res. Int. 44 (2011) 391-396.

[26] Naasani I., Oh-Hashi F., Oh-Hara T., Feng W. Y., Johnston J., Chan K., et al, Cancer Res. 63 (2003) 824-830.

[27] Dorman H. J. D., Peltoket A., Hiltunen R., Tikkanen M. J., Food Chemistry 83 (2003) 255-262.

[28] Özçelik B., Orhan I., Toker G., A Journal of Biosciences 61c (2006) 632- 638.

[29] Baliga M. S., Baliga B. R., Kandathil S..M., Bhat H. P., Vayalil P. K., Food Res. Int. 44 (2011) 1812-1822. 